\title{
Effects of Molybdenum, Nickel, and Nitrogen Sources on the Mineral Nutrition and Growth of Rice Plants
}

\author{
Milton Ferreira Moraes, ${ }^{1}$ André Rodrigues Reis, ${ }^{1,4}$ Larissa Alexandra C. \\ Moraes, ${ }^{2}$ José Lavres-Junior, ${ }^{1}$ Rafael Vivian, ${ }^{3}$ Cleusa Pereira Cabral, ${ }^{1}$ and \\ Eurípedes Malavolta ${ }^{1}$ \\ ${ }^{1}$ Center for Nuclear Energy in Agriculture, University of Sao Paulo, Brazil \\ ${ }^{2}$ Western Amazon Research Center of the Brazilian Agricultural Research \\ Corporation (EMBRAPA), Manaus, Brazil \\ ${ }^{3}$ Luiz de Queiroz College of Agriculture, University of Sao Paulo, Piracicaba, \\ Brazil \\ ${ }^{4}$ Department of Civil and Environmental Engineering, Waseda University, \\ Shinjuku-ku, Tokyo, Japan
}

\begin{abstract}
Upland rice plants, cultivar 'IAC 202,' were grown in nutrient solution until full tillering. Treatments consisted of ammonium nitrate (AN) or urea (UR) as nitrogen $(\mathrm{N})$ source plus molybdenum $(\mathrm{Mo})$ and/or nickel $(\mathrm{Ni}): \mathrm{AN}+\mathrm{Mo}+\mathrm{Ni}$, $\mathrm{AN}+\mathrm{Mo}-\mathrm{Ni}, \mathrm{AN}-\mathrm{Mo}+\mathrm{Ni}, \mathrm{UR}+\mathrm{Mo}+\mathrm{Ni}, \mathrm{UR}+\mathrm{Mo}-\mathrm{Ni}$, and $\mathrm{UR}-\mathrm{Mo}$ $+\mathrm{Ni}$. The experiment was carried out to better understand the effect of these treatments on dry-matter yield, chlorophyll, net photosynthesis rate, nitrate $\left(\mathrm{NO}_{3}{ }^{-}-\mathrm{N}\right)$, total $\mathrm{N}$, in vitro activities of urease and nitrate reductase (NR), and Mo and Ni concentrations. In UR-grown plants, Mo and Ni addition increased yield of dry matter. Regardless of the $\mathrm{N}$ source, chlorophyll concentration and net photosynthesis rate were reduced when $\mathrm{Mo}$ or $\mathrm{Ni}$ were omitted, although not always significantly. The omission of either Mo or Ni led to a decrease in urease activity, independent of $\mathrm{N}$ source. Nitrate reductase activity increased in nutrient solutions without Mo, although $\mathrm{NO}_{3}{ }^{-}-\mathrm{N}$ increased. There was not a consistent
\end{abstract}

Received 18 January 2009, Accepted 7 May 2009

This article is dedicated to the memory of Prof. Euripedes Malavolta; his example and passion for teaching will always be remembered.

Address correspondence to M. F. Moraes, Centro de Energia Nuclear na Agricultura, Laboratório de Nutrição Mineral de Plantas, Av. Centenário, 303, CEP 13400-970, Piracicaba, Brazil. E-mail: moraesmf@yahoo.com.br 
variation in total $\mathrm{N}$ concentration. Molybdenum and $\mathrm{Ni}$ concentration in roots and shoots were influenced by their supply in the nutrient solution. Molybdenum concentration was not influenced by $\mathrm{N}$ sources, whereas $\mathrm{Ni}$ content in both root and shoots was greater in ammonium nitrate-grown plants. In conclusion, it can be hypothesized that there is a relationship between $\mathrm{Mo}$ and $\mathrm{Ni}$ acting on photosynthesis, although is an indirect one. This is the first evidence for a beneficial effect of $\mathrm{Mo}$ and $\mathrm{Ni}$ interaction on plant growth.

Keywords: Chlorophyll, micronutrients, nitrate reductase, photosynthesis, plant nutrition, urease

\section{INTRODUCTION}

Molybdenum (Mo) was established to be essential in higher plants by Arnon and Stout (1939). Molybdenum is known as a constituent of enzymes such as nitrate reductase (EC 1.6.6.1), which reduces nitrate to nitrite, and the enzyme nitrogenase (EC 1.18.6.1), which reduces molecular nitrogen $(\mathrm{N})$ to ammonia in all $\mathrm{N}$-fixing organisms. Further details can be found elsewhere (Hewitt and Smith 1975; Epstein and Bloom 2005; Malavolta 2006).

Representative soils of Sao Paulo state, Brazil, analyzed by Bataglia, Furlani, and Valadares (1975), showed total Mo content between 0.11 and $3.73 \mathrm{mg} \mathrm{kg}^{-1}$ and soluble content in ammonium oxalate extractant from 0.01 to $0.03 \mathrm{mg} \mathrm{kg}^{-1}$. Symptoms of deficiency and amelioration by Mo addition have been observed in several crops, particularly in legumes.

Nickel (Ni) meets the direct (Dixon et al. 1975) and indirect (Eskew, Welch, and Cary 1983) criteria of essentiality. Urease (EC 3.5.1.5) is a ubiquitous metalloenzyme containing $\mathrm{Ni}$, which splits urea hydrolytically into ammonia $\left(\mathrm{NH}_{3}\right)$ and carbon dioxide $\left(\mathrm{CO}_{2}\right)$. Ammonia ions released by urea hydrolysis are incorporated into glutamate (Gerendás, $\mathrm{Zu}$, and Sattelmacher 1998). Wood, Reilly, and Nyczepir (2004) and Ruter (2005) diagnosed Ni deficiency under field conditions, in the United States, in pecan (Carya illinoinensis) and river birch (Betula nigra), respectively. Bertrand and DeWolff (1973) observed that soybean cultivated in a soil low in $\mathrm{Ni}$ had increased nodulation and grain yield resulting from $\mathrm{Ni}$ fertilization up to $40 \mathrm{~g} \mathrm{ha}^{-1}$. Leaf symptoms are characterized by dark spots and an anatomical deformation causing leaf rounding, known as "mouse ear" (Wood, Reilly, and Nyczepir 2004). Necrotic spots associated with $\mathrm{Ni}$ deficiency correspond to local accumulation of either urea (Shimada et al. 1980; Welch 1981) or oxalic and lactic acids (Bai, Reilly, and Wood 2006), indicating disturbance in $\mathrm{N}$ and carbon (C) metabolism.

Analyses of 38 samples of Brazilian soils from Sao Paulo state showed that total $\mathrm{Ni}$ varied in the range of less than 10 to $127 \mathrm{mg} \mathrm{kg}^{-1}$. 
Soluble diethylenetriaminepentaacetic acid (DTPA) Ni ranged from less than 0.5 to a maximum of $1.4 \mathrm{mg} \mathrm{kg}^{-1}$, considered as low values (Rovers, Camargo, and Valadares 1983). Soils of pecan orchards in the United States, where Ni deficiency was observed and corrected through foliar spray of $\mathrm{Ni}$ sulfate, showed 0.4 to $1.4 \mathrm{~kg} \mathrm{ha}^{-1}$ of $\mathrm{Ni}$, equivalent to approximately 0.2 to $0.7 \mathrm{mg} \mathrm{kg}^{-1}$ (Wood, Reilly, and Nyczepir 2006).

It was observed that $\mathrm{Ni}$ stimulated the in vitro nitrate reductase (NR) activity of young grain sorghum and sudangrass leaf tissue as a result of reversion of cyanide inhibition (Maranville 1970). Nickel-deficient barley can accumulate more nitrate $\left(\mathrm{NO}_{3}{ }^{-}-\mathrm{N}\right)$ than plants that have sufficient $\mathrm{Ni}$ (Brown, Welch, and Madison 1990). This effect is explained through the role of $\mathrm{Ni}$ in activation of L-Malate:NAD oxidoreductase (MDH) involved in nicotinamide adenine dinucleotide (NADH) production, which is required for nitrate reduction. Kevresan et al. (1998) grew sugar beet plants in water solution with cadmium (Cd), Mo, and Ni containing $0,0.1,10$, or $1,000 \mu \mathrm{M}$ of each element. Activities of nitrate reductase and glutamine synthetase, and protein content were reduced by $\mathrm{Ni}$, whereas Mo stimulated these parameters. In a similar study, Kevresan et al. (2001) observed that $\mathrm{Ni}$ and Mo led to a reduction of nitrate content in shoots more than roots of pea plants. In low concentration, $\mathrm{Ni}$ increased dry matter of both shoot and roots.

Investigations on both $\mathrm{Ni}$ and urease and on Mo and nitrate reductase are plentiful (Mulder, Boxma, and Veen 1959; Eskew, Welch, and Norvell 1984; Martin, Saco, and Alvarez, 1995; Saco, Martin, and Alvarez 1995; Gerendás and Sattelmacher 1997a, 1997b; Gerendás, Zhu, and Sattelmacher 1998; Bai, Reilly, and Wood 2006). However, there are few works that relate these two micronutrients, direct or implicitly, with each of these two enzymes. The aims of the current work were to measure the effect of Mo and Ni on dry-matter yield of rice plants supplied with two $\mathrm{N}$ sources (ammonium nitrate and urea) and to evaluate the influence of Mo and $\mathrm{Ni}$ on variables related to dry-matter yield, such as activity of both urease and nitrate reductase, chlorophyll, net photosynthesis rate, total $\mathrm{N}$, nitrate content, and Mo and Ni concentrations in roots and shoots..

\section{MATERIAL AND METHODS}

A greenhouse experiment was carried out at the Plant Nutrition Laboratory of the Center for Nuclear Energy in Agriculture (CENA), University of Sao Paulo (USP), Piracicaba, SP, Brazil. Seeds of upland rice (Oryza sativa L. cv. 'IAC 202') were germinated in vermiculite moistened with $0.1 \mathrm{mM}$ calcium sulfate $\left(\mathrm{CaSO}_{4} \cdot 2 \mathrm{H}_{2} \mathrm{O}\right)$. Seedlings were transfered to $40-\mathrm{L}$ plastic trays with a wooden perforated cover when they reached $5 \mathrm{~cm}$ high and were fixed with plastic foam around the 
Table 1. Composition of the nutrient solutions ${ }^{a}$

\begin{tabular}{lc}
\hline Nutrient & Amount \\
\hline $\mathrm{N}\left(\mathrm{NH}_{4} \mathrm{NO}_{3}\right.$ or urea $)\left(\mathrm{mmol} \mathrm{L}^{-1}\right)$ & 6.00 \\
$\mathrm{~K}\left(\mathrm{mmol} \mathrm{L}^{-1}\right)$ & 2.00 \\
$\mathrm{P}\left(\mathrm{mmol} \mathrm{L}^{-1}\right)$ & 0.25 \\
$\mathrm{Mg}\left(\mathrm{mmol} \mathrm{L}^{-1}\right)$ & 0.50 \\
$\mathrm{Ca}\left(\mathrm{mmol} \mathrm{L}^{-1}\right)$ & 2.00 \\
$\mathrm{Fe}-\mathrm{EDTA}\left(\mu \mathrm{mol} \mathrm{L}^{-1}\right)$ & 89.5 \\
$\mathrm{~B}\left(\mu \mathrm{mol} \mathrm{L}^{-1}\right)$ & 25.0 \\
$\mathrm{Mn}\left(\mu \mathrm{mol} \mathrm{L}^{-1}\right)$ & 2.0 \\
$\mathrm{Zn}\left(\mu \mathrm{mol} \mathrm{L}^{-1}\right)$ & 2.0 \\
$\mathrm{Cu}\left(\mu \mathrm{mol} \mathrm{L}^{-1}\right)$ & 0.5 \\
$\mathrm{Mo}\left(\mu \mathrm{mol} \mathrm{L}^{-1}\right)$ & 0.5 \\
$\mathrm{Ni}\left(\mu \mathrm{mol} \mathrm{L}^{-1}\right)$ & 0.5 \\
\hline
\end{tabular}

${ }^{a}$ Modified from Gerendás et al. (1998) and Epstein and Bloom (2005); Mo and $\mathrm{Ni}$ were omitted according to each treatment; $\mathrm{NH}_{4} \mathrm{NO}_{3}$, ammonium nitrate (AN).

bottom part of their culms. Plants were grown in aerated one-fifthstrength Johnson's solution (Johnson et al. 1957). After 2 weeks, two plants were put in 2-L plastic pots containing full-strength nutrient solution (Table 1), modified from Gerendás, Zhu, and Sattelmacher (1998) and Epstein and Bloom (2005). Nutrient solutions were kept under constant aeration, and their $\mathrm{pH}$ was adjusted to 5.8 whenever needed. Nutrient solutions were renewed every week. Analytical-grade reagents and deionized water from ion-exchange-resin treatment were used in this experiment. The treatments are shown in Table 2. Six replicates in a completely randomized design were used.

Five weeks after the start of treatments, two middle leaves from two plants in each treatment were collected to assay urease activity according to method described by Hogan, Swift, and Done (1983), with $\mathrm{NH}_{3}$ determined as suggested by McCullough (1967). One week later, new leaf samples were taken using the same procedure to assay NR activity, according to a simplified technique (Mulder, Boxma, and Veen 1959).

Table 2. Distribution of treatments in the experiment

\begin{tabular}{ll}
\hline Pot number & Variables $^{a}$ \\
\hline $1-6$ & AN + Mo + Ni \\
$7-12$ & AN + Mo - Ni \\
$13-18$ & AN - Mo + Ni \\
$19-24$ & UR + Mo + Ni \\
$25-30$ & UR + Mo - Ni \\
$31-36$ & UR $-\mathrm{Mo}+\mathrm{Ni}$ \\
\hline
\end{tabular}

${ }^{a} \mathrm{AN}$ : ammonium nitrate; UR, urea; + and -, with and without addition, respectively. 
Nine weeks after start of treatments, the following determinations were made: Leaf sampling for chlorophyll analysis was carried out as described previously, and analyzed according to Arnon (1949). Indirect chlorophyll measurements were performed with a portable Minolta SoilPlant Analysis Development (SPAD) 502 chlorophyll meter (Minolta Camera Co. Ltd., Tokyo, Japan), using the medium portion of top leaves but avoiding central ribbing; net photosynthesis rate was measured and calculated with an infrared gas analyzer (IRGA) Li-COR 6400 model (LiCOR, Inc., Lincoln, Neb.), with $1600 \mu$ mol photons $\mathrm{m}^{-2} \mathrm{~s}^{-1}$. Shoots and roots were harvested, rinsed with distilled water, and oven dried at $65^{\circ} \mathrm{C}$ to constant weight, and their weights were recorded. Plant materials were ground to pass a $1-\mathrm{mm}$ sieve and digested, and total $\mathrm{N}, \mathrm{Ni}$, and $\mathrm{Mo}$ were analyzed according to Malavolta, Vitti, and Oliveira (1997). Soluble $\mathrm{NO}_{3}-\mathrm{N}$ in shoots was determined as described by Bray (1948).

Statistical analyses were performed using Statistical Analysis System (SAS) software for Windows 6.11 (SAS 1996). Analysis of variance (Ftest) was employed to evaluate significance of treatments. Tukey's test was used for means separation.

\section{RESULTS AND DISCUSSION}

Effects of treatments on dry-matter yield are shown in Table 3. Molybdenum and Ni caused different effects on plant growth depending on $\mathrm{N}$ sources. Regarding $\mathrm{N}$ sources, dry-matter yield was greater in ureagrown plants treated with $\mathrm{Mo}$ and $\mathrm{Ni}$, likely because ammonia ions generated by hydrolysis of urea passively taken up by roots through

Table 3. Dry-matter yield of rice plants (g per pot)

\begin{tabular}{llcc}
\hline Treatments $^{a}$ & \multicolumn{3}{c}{ Parts of plant } \\
\cline { 2 - 4 } & Root & Shoot & Total \\
\hline $\mathrm{AN}+\mathrm{Mo}+\mathrm{Ni}$ & $1.9 \mathrm{~b}$ & $5.6 \mathrm{c}$ & $7.5 \mathrm{~d}$ \\
$\mathrm{AN}+\mathrm{Mo}-\mathrm{Ni}$ & $2.0 \mathrm{ab}$ & $7.2 \mathrm{bc}$ & $9.2 \mathrm{bc}$ \\
$\mathrm{AN}-\mathrm{Mo}+\mathrm{Ni}$ & $1.8 \mathrm{~b}$ & $7.7 \mathrm{~b}$ & $9.5 \mathrm{~b}$ \\
$\mathrm{UR}+\mathrm{Mo}+\mathrm{Ni}$ & $2.3 \mathrm{a}$ & $8.9 \mathrm{a}$ & $11.2 \mathrm{a}$ \\
$\mathrm{UR}+\mathrm{Mo}-\mathrm{Ni}$ & $2.3 \mathrm{a}$ & $7.0 \mathrm{c}$ & $9.3 \mathrm{bc}$ \\
UR $-\mathrm{Mo}+\mathrm{Ni}$ & $2.2 \mathrm{ab}$ & $6.3 \mathrm{~d}$ & $8.5 \mathrm{c}$ \\
F-test & $*$ & $* *$ & $* *$ \\
CV $(\%)$ & 4.9 & 1.9 & 2.3 \\
\hline
\end{tabular}

${ }^{a} \mathrm{AN}$, ammonium nitrate; UR, urea.

*, **Significant at 5 and $1 \%$ levels, respectively.

Note. The same letter in a given column indicates, nonsignificant differences at the $5 \%$ level by the Tukey test. 
transmembrane channel are incorporated in organic compounds without prior reduction. On the other hand, in ammonium nitrate treatments, energy is required for active ammonium $\left(\mathrm{NH}_{4}{ }^{+}-\mathrm{N}\right)$ and $\mathrm{NO}_{3}{ }^{-}-\mathrm{N}$ absorption by roots as well as carbon and protons consumed by the nitrate reduction process (Crawford et al. 2000).

Dry-matter yield was reduced in ammonium nitrate-grown plants supplied with $\mathrm{Mo}$ and $\mathrm{Ni}$, compared with $\mathrm{Mo}$ - and $\mathrm{Ni}$-deprived plants in the ammonium nitrate ( $\mathrm{AN}$ or $\mathrm{NH}_{4} \mathrm{NO}_{3}$ ) treatment (Table 3). Because of the role of $\mathrm{Ni}$ as a component of the urease enzyme, which splits urea hydrolytically into $\mathrm{NH}_{3}$ and $\mathrm{CO}_{2}$, low $\mathrm{Ni}$ consumption in $\mathrm{NH}_{4} \mathrm{NO}_{3}$ treatments was expected. Therefore, in this case, Ni supply did not lead to a toxic accumulation, because there was greater $\mathrm{Ni}$ concentration in plants with no growth reduction. Molybdenum is necessary to activate nitrate reductase (Hewitt and Smith 1975), but sometimes Mo supplied in solution can interfere with absorption of micronutrients (Fargasova 1999). This may explain the greater dry-matter content in plants grown without Mo. Urea-grown plants need less Mo because urea is a reduced $\mathrm{N}$ source, but reduced dry-matter yield in Mo-deprived plants was observed. However, those plants did not show any Mo-deficiency symptoms, maybe because concentration of Mo in plant tissue was high enough for growth. A plausible explanation for this finding is still required.

Table 4 shows the treatment effect on the net photosynthesis rate and chlorophyll concentration in rice leaves. Chlorophyll index when indirectly evaluated (SPAD units) was not affected by either $\mathrm{N}$ sources or Mo deprivation; on the other hand, it was influenced by $\mathrm{Ni}$ deprivation. Data on total chlorophyll measurements presented the greatest values in urea-grown plants, which does not agree with the indirect measurement; chlorophyll concentration was weak in treatments with both Mo and Ni deprivation, independent of $\mathrm{N}$ sources.

Similar studies in the literature regarding the relationships of $\mathrm{N}$ sources, $\mathrm{Ni}$, and $\mathrm{Mo}$ on plant nutrition were not found. Usually, information about $\mathrm{Ni}$ effects is related to urea as a $\mathrm{N}$ source. Wong and Chang (1991) observed significant increase of chlorophyll concentration in Chlorella pyrenoidosa (freshwater algae) when $\mathrm{Ni}$ concentration ranged from 0.1 to $1.0 \mathrm{mg} \mathrm{L}^{-1}$ in the culture medium. McIlveen and Negusanti (1994) noticed that among several organelles, chloroplasts contained the greatest $\mathrm{Ni}$ content, between 8.0 and $9.9 \%$ of the total content, while other organelles such as mitochondria and ribosomes showed from 0.32 to $2.85 \%$. Nickel effects on chlorophyll concentration depend on doses and plant species; it can be negative for barley and tomato or positive for maize, oat, and potato.

In tomato plants, Tan, Ikeda, and Oda (2000) observed strong chlorophyll concentration when urea was amended with $\mathrm{Ni}$, whereas $\mathrm{AN}$ 
Table 4. Effect of $\mathrm{N}$ sources, Mo, and $\mathrm{Ni}$ on SPAD units, chlorophyll, and net photosynthesis rate

\begin{tabular}{lccccc}
\hline Treatments $^{a}$ & SPAD units & $\begin{array}{c}\text { Chlorophyll a } \\
\left(\mu \mathrm{g} \mathrm{mL}^{-1}\right)\end{array}$ & $\begin{array}{c}\text { Chlorophyll b } \\
\left(\mu \mathrm{g} \mathrm{mL}^{-1}\right)\end{array}$ & $\begin{array}{c}\text { Total chlorophyll } \\
\left(\mu \mathrm{g} \mathrm{mL}^{-1}\right)\end{array}$ & $\begin{array}{c}\text { Net photosynthesis rate } \\
\left(\mu \mathrm{mol} \mathrm{CO}_{2} \mathrm{~m}^{-2} \mathrm{~s}^{-1}\right)\end{array}$ \\
\hline $\mathrm{AN}+\mathrm{Mo}+\mathrm{Ni}$ & $40.05 \mathrm{abc}$ & $1.52 \mathrm{c}$ & $0.70 \mathrm{a}$ & $2.22 \mathrm{c}$ & $24.18 \mathrm{ab}$ \\
$\mathrm{AN}+\mathrm{Mo}-\mathrm{Ni}$ & $36.82 \mathrm{~d}$ & $0.57 \mathrm{~d}$ & $0.31 \mathrm{~b}$ & $0.88 \mathrm{~d}$ & $20.27 \mathrm{~b}$ \\
$\mathrm{AN}-\mathrm{Mo}+\mathrm{Ni}$ & $39.62 \mathrm{bc}$ & $1.00 \mathrm{~d}$ & $0.33 \mathrm{~b}$ & $1.33 \mathrm{~d}$ & $20.25 \mathrm{~b}$ \\
$\mathrm{UR}+\mathrm{Mo}+\mathrm{Ni}$ & $41.98 \mathrm{a}$ & $3.73 \mathrm{a}$ & $0.62 \mathrm{ab}$ & $4.35 \mathrm{a}$ & $28.46 \mathrm{a}$ \\
$\mathrm{UR}+\mathrm{Mo}-\mathrm{Ni}$ & $37.98 \mathrm{~cd}$ & $1.92 \mathrm{c}$ & $0.66 \mathrm{a}$ & $2.58 \mathrm{c}$ & $26.99 \mathrm{a}$ \\
$\mathrm{UR}-\mathrm{Mo}+\mathrm{Ni}$ & $41.70 \mathrm{ab}$ & $2.64 \mathrm{~b}$ & $0.58 \mathrm{~b}$ & $3.22 \mathrm{~b}$ & $21.55 \mathrm{~b}$ \\
F-test & $* *$ & $* *$ & $* *$ & $* *$ & $* 3$ \\
CV $(\%)$ & 3.2 & 9.3 & 21.5 & 8.2 & 10.6 \\
\hline
\end{tabular}

${ }^{a} \mathrm{AN}$, ammonium nitrate; UR, urea.

**Significant at the $1 \%$ level.

Note. The same letter in a given column indicates nonsignificant differences at the $5 \%$ level by Tukey test. 
Favorable Ni effect was expected and indeed observed for both $\mathrm{N}$ sources. Gerendás and Sattelmacher (1997b) observed reduction of urease activity in Ni-deprived plants growing with both urea and ammonium nitrate. However, urease activity was greater in urea-grown plants. In our work, Mo and $\mathrm{Ni}$ together led to an increased urease activity greater than each element supplied separately. It is possible that in urea-grown plants without Mo or Ni, urease activity was not greater, due to either its inhibition by $\mathrm{NH}_{4}{ }^{+}-\mathrm{N}$ excess produced during urea hydrolysis (Matsumoto et al. 1966) or excessive accumulation of urea in plant tissues. To our knowledge, Mo $+\mathrm{Ni}$ or Mo effects on urease activity have not been reported, and the results observed in this work do not allow a full explanation of the processes behind it.

Nitrate reductase activity was influenced by both $\mathrm{N}$ sources, and it was greater in ammonium nitrate-grown plants (Table 5). Nitrate ions induce NR activation, which needs Mo for its activity. An unexpected increase in NR was caused by Mo deprivation. Nickel-deprived plants grown with $\mathrm{NH}_{4} \mathrm{NO}_{3}$ presented reduction in this enzyme when compared to those grown with full $\mathrm{Ni}$ supply. In the available literature, no similar research was found. Nitrate reductase activity observed in urea treatments came from nitrate uptake, when young plants were supplied with diluted nutrient solution. Nickel effect on increasing NR activity is not in agreement with findings by Kevresan et al. (1998), which suggests no stimulating action by this micronutrient.

It may be possible that some $\mathrm{Mo}$ and $\mathrm{Ni}$ are present even in treatments in which no Mo or Ni were added. The amounts of Mo or $\mathrm{Ni}$ required by plants are very small, and there may have been some Mo and $\mathrm{Ni}$ contaminants from other components of the nutrient solution (Table 6).

Nitrate content was influenced by both $\mathrm{N}$ sources. Molybdenumdeprived plants growing with $\mathrm{NH}_{4} \mathrm{NO}_{3}$ plus $\mathrm{Ni}$ had their nitrate content increased, although nitrate reductase activity increased significantly. Studies of $\mathrm{Ni}$ effect on $\mathrm{N}$ metabolism have shown variable results, possibly in response to imposed experimental conditions. Brown, Welch, and Madison (1990) grew barley in nutrient solution containing ammonium and nitric $\mathrm{N}$, and they observed an increase of nitrate content in Ni-deprived treatments; perhaps because $\mathrm{Ni}$ activates $\mathrm{MDH}$, which produces the NADH required for nitrate reduction. According to Kevresan et al. (2001), young pea plants fertilized with Ni under soil conditions had less tissue nitrate. A clear relationship has not been established among $\mathrm{Ni}, \mathrm{NR}$ activity, and nitrate content. In our experiment, total $\mathrm{N}$ in ammonium nitrate-grown plants was not affected by either Mo or Ni treatments. However, Mo-deprived plants grown with urea had a significant total $\mathrm{N}$ reduction, the least NR activity, and the weakest $\mathrm{NO}_{3}{ }^{-}-\mathrm{N}$ concentration. 
Table 6. Treatment effects on Mo and Ni concentrations

\begin{tabular}{lccccc}
\hline Treatments $^{a}$ & \multicolumn{2}{c}{ Molybdenum $\left(\mathrm{mg} \mathrm{kg}^{-1}\right)$} & & \multicolumn{2}{c}{ Nickel $\left(\mathrm{mg} \mathrm{kg}^{-1}\right)$} \\
\cline { 2 - 3 } \cline { 5 - 6 } \cline { 5 - 6 } & Root & Shoot & & Root & Shoot \\
\hline $\mathrm{AN}+\mathrm{Mo}+\mathrm{Ni}$ & $4.6 \mathrm{~b}$ & $2.5 \mathrm{a}$ & & $12.6 \mathrm{~b}$ & $4.2 \mathrm{ab}$ \\
$\mathrm{AN}+\mathrm{Mo}-\mathrm{Ni}$ & $8.3 \mathrm{a}$ & $2.2 \mathrm{ab}$ & & $0.8 \mathrm{c}$ & $1.6 \mathrm{c}$ \\
$\mathrm{AN}-\mathrm{Mo}+\mathrm{Ni}$ & $0.7 \mathrm{c}$ & $0.9 \mathrm{c}$ & & $20.5 \mathrm{a}$ & $4.5 \mathrm{a}$ \\
$\mathrm{UR}+\mathrm{Mo}+\mathrm{Ni}$ & $5.2 \mathrm{~b}$ & $2.0 \mathrm{abc}$ & & $3.2 \mathrm{c}$ & $3.3 \mathrm{abc}$ \\
$\mathrm{UR}+\mathrm{Mo}-\mathrm{Ni}$ & $4.7 \mathrm{~b}$ & $2.6 \mathrm{a}$ & & $2.8 \mathrm{c}$ & $1.3 \mathrm{c}$ \\
UR - Mo + Ni & $0.5 \mathrm{c}$ & $1.0 \mathrm{bc}$ & & $4.0 \mathrm{c}$ & $2.3 \mathrm{bc}$ \\
F-test & $* *$ & $* *$ & & $* *$ & $* *$ \\
CV $(\%)$ & 17.7 & 16.9 & & 18.7 & 17.7 \\
\hline
\end{tabular}

${ }^{a} \mathrm{AN}$, ammonium nitrate; UR, urea.

**, *Significant at $1 \%$ and $5 \%$ levels, respectively.

Note. The same letter in a given column indicates nonsignificant differences at the $5 \%$ level by Tukey test.

Molybdenum and Ni contents in roots and shoots are shown in Table 6. There was no effect of $\mathrm{N}$ sources on shoot Mo concentration, but Ni supply reduced root Mo concentration in ammonium nitrate-grown plants. On the other hand, $\mathrm{N}$ sources influenced $\mathrm{Ni}$ concentration, with ammonium nitrate-grown plants showing more $\mathrm{Ni}$ both in roots and shoots. Gerendás, Zhu, and Sattlemacher (1998) cultivated rice plants in nutrient solution with $\mathrm{NH}_{4} \mathrm{NO}_{3}$ or urea and also found greater shoot $\mathrm{Ni}$ concentration in ammonium nitrate-supplied plants. The greatest $\mathrm{Ni}$ concentration in ammonium nitrate-grown plants does not relate to greatest urease activity (Table 5). It is possible that this $\mathrm{Ni}$ increase is related to luxury consumption of $\mathrm{Ni}$, because a dilution effect was not noticed. A relationship between shoot Mo concentration and NR activity was not observed (Table 5).

Molybdenum and Ni concentrations reported in the literature show a great range as a consequence of plant species and environmental growth conditions, which makes comparisons with our data difficult. At the tillering stage, Mo concentrations ranging from 0.5 to $2.0 \mathrm{mg} \mathrm{kg}^{-1}$ are considered adequate in rice (Fageria 1984). In general, toxic Mo concentrations range between 10 and $50 \mathrm{mg} \mathrm{kg}^{-1}$ (Kabata-Pendias and Pendias 2001). Therefore, our results for Mo and Ni concentrations cannot be considered toxic or excessive. High $\mathrm{Ni}$ doses can cause reduction of Mo concentration in barley and citrus, suggesting a possible antagonism between these two micronutrients (Sato 1969; Brune and Dietz 1995), although this behavior was not verified in the present study. In red clover cultivated in pot soil (Elmosly and Abdel-Sabour 1997), shoot $\mathrm{Ni}$ concentrations ranged from 0.5 to $1.1 \mathrm{mg} \mathrm{kg}^{-1}$ in non-Nifertilized plants and from 7.5 to $14.0 \mathrm{mg} \mathrm{kg}^{-1}$ in Ni-fertilized plants. 
According to these authors, there was growth reduction at $\mathrm{Ni}$ concentration up to $7.5,14.0$, and $5.3 \mathrm{mg} \mathrm{kg}^{-1}$, respectively, on alluvial soils with pH of 8.2 (silt loam), 7.9 (sandy loam), and 7.6 (sandy).

Critical levels for $\mathrm{Ni}$ in barley are between 11 and $19 \mathrm{mg} \mathrm{kg}^{-1}$ (Mcllveen and Negusanti 1994), whereas toxic concentrations vary among species, reaching a maximum of $332 \mathrm{mg} \mathrm{kg}^{-1}$ in celery plants. Gupta, RamKala, and Gupta (1996) analyzed several plant species grown in Nifertilized soil and found concentrations equivalent to 12,11 , and $21 \mathrm{mg} \mathrm{kg}^{-1}$ to be adequate for wheat, barley, and oat, respectively, and concentrations of $19-25,18-26$, and $25-50 \mathrm{mg} \mathrm{kg}^{-1}$ to be toxic for these plants. In general, $\mathrm{Ni}$ concentrations ranging from 0.05 to $5.0 \mathrm{mg} \mathrm{kg}^{-1}$ are considered satisfactory for plant growth and excessive or toxic Ni concentrations can range from 25 to $50 \mathrm{mg} \mathrm{kg}^{-1}$ (Malavolta and Moraes 2007). According to Kabata-Pendias and Pendias (2001), Ni concentrations ranging from 1 to $10 \mathrm{mg} \mathrm{kg}^{-1}$ are acceptable to most cultivated plants. Kevresan et al. (2001) found toxic Mo and Ni concentrations in shoots of pea plants to be more than 357 to $813 \mathrm{mg} \mathrm{kg}^{-1}$, respectively. In roots, the corresponding values were 480 and $2,262 \mathrm{mg} \mathrm{kg}^{-1}$, respectively.

\section{CONCLUSIONS}

Molybdenum and Ni effects in rice growth depend on the $\mathrm{N}$ source. It is likely that urease activity is reduced as a consequence of both $\mathrm{Mo}$ and $\mathrm{Ni}$ omission. We hypothesize that an indirect relationship between Mo and $\mathrm{Ni}$ takes place in plant nutrition, perhaps by stimulating chlorophyll production and net photosynthesis rate.

\section{ACKNOWLEDGMENTS}

We thank Dr. Jonathan J. Hart (USDA-ARS/Cornell University) for his valuable comments on the manuscript and also our colleagues Saulo de Tarso Aidar and Daniel Manfredini for their assistance in the plant analyses. This work was supported by fellowships awarded from the National Council for Scientific and Technological Development (CNPq), Sao Paulo Research Foundation (FAPESP), and Coordination of the Perfecting of Personnel of Higher Level (CAPES).

\section{REFERENCES}

Arnon, D. I. 1949. Cooper enzymes in isolated chloroplasts: Polyphenoloxydase in Beta vulgaris. Plant Physiology 24:1-15. 
Arnon, D. I., and P. R. Stout. 1939. The essentiality of certain elements in minute quantity for plants with special reference to copper. Plant Physiology 14:371375.

Bai, C., C. C. Reilly, and B. W. Wood. 2006. Nickel deficiency disrupts metabolism of ureides, amino acids, and organic acids of young pecan foliage. Plant Physiology 140:433-443.

Bataglia, O. C., P. R. Furlani, and J. M. A. S. Valadares. 1975. Molybdenum in soils of the Sao Paulo state. In 15th Congresso Brasileiro de Ciência do solo, 107-111. Campinas, Brazil: Brazilian Soil Science Society (in Portuguese).

Bertrand, D., and A. DeWolff. 1973. Importance of nickel as oligoelement for rhizobium of nodosities of leguminosae. Comptes Rendus Hebdomadaires des Seances de L'Academie des Sciences Serie D 276:1855-1858 (in French).

Bray, R. H. 1948. Correlation of soil tests with crop response to added fertilizers and fertilizer requirements. In Diagnostic techniques for soils and crops, ed. H. B. Kitchen, 53-86. Washington, D.C.: American Potash Institute.

Brown, P. H., R. M. Welch, and J. T. Madison. 1990. Effect of nickel deficiency on soluble anion, amino-acid, and nitrogen levels in barley. Plant and Soil 125:19-27.

Brune, A., and K. J. Dietz. 1995. A comparative analysis of element composition of roots and leaves of barley seedlings grown in the presence of toxic cadmium, molybdenum, nickel, and zinc concentrations. Journal of Plant Nutrition 18:853-868.

Crawford, N. M., M. L. Kahn, T. Leustek, and S. R. Long. 2000. Nitrogen and sulfur. In Biochemistry and molecular biology of plants, ed. B. Buchanan, W. Gruissem, and R. L. Jones, 786-849. Rockville, Md.: American Society of Plant Physiologists.

Dixon, N. E., C. Gazzola, R. L. Blakeley, and B. Zerner. 1975. Jack bean urease (EC 3.5.1.5), a metalloenzyme: Simple biological role for nickel? Journal of the American Chemical Society 97:4131-4133.

Elmosly, W. A., and M. F. Abdel-Sabour. 1997. Transfer characteristics and uptake of nickel by red clover grown on nickel amended alluvial soils of an arid zone. Agriculture Ecosystems and Environment 65:49-57.

Epstein, E., and A. J. Bloom, 2005. Mineral nutrition of plants: Principles and perspectives, 2nd ed. Sunderland, Mass.: Sinauer Associates.

Eskew, D. L., R. M. Welch, and E. E. Cary. 1983. Nickel: An essential micronutrient for legumes and possibly all higher plants. Science 222:621-623.

Eskew, D. L., R. M. Welch, and W. A. Norvell. 1984. Nickel in higher plants: Further evidence for an essential role. Plant Physiology 76:691-693.

Fageria, N. K. 1984. Fertilization and mineral nutrition of rice. Goiânia/Rio de Janeiro, Brazil: EMBRAPA-CNPAF/Editora Campus (in Portuguese).

Fargasova, A. 1999. Determination of metal interactions on root growth of Sinapis alba seedlings. Biologia Plantarum 42:637-640.

Gerendás, J., and B. Sattelmacher. 1997a. Significance of Ni supply for growth, urease activity and the concentrations of urea, amino acids, and mineral nutrients of urea-grown plants. Plant and Soil 190:153-162.

Gerendás, J., and B. Sattelmacher. 1997b. Significance of N source (urea vs. $\mathrm{NH}_{4} \mathrm{NO}_{3}$ ) and $\mathrm{Ni}$ supply for growth, urease activity, and nitrogen metabolism of zucchini (Cucurbita pepo convar. giromontiina). Plant and Soil 196:217-222. 
Gerendás, J., and B. Sattelmacher. 1999. Influence of Ni supply on growth and nitrogen metabolism of Brassica napus $\mathrm{L}$. grown with $\mathrm{NH}_{4} \mathrm{NO}_{3}$ or urea as $\mathrm{N}$ source. Annals of Botany 83:65-71.

Gerendás, J., Z. Zhu, and B. Sattelmacher. 1998. Influence of N and Ni supply on nitrogen metabolism and urease activity in rice (Oryza sativa L.). Journal of Experimental Botany 49:1545-1554.

Gupta, S. P., Ram-Kala, and V. K. Gupta. 1996. A note on effect of nickel application on rabi cereals. New Botanist 23:237-239.

Hewitt, E. J., and T. A. Smith. 1975. Plant mineral nutrition. London: English Universities Press.

Hogan, M. E., I. E. Swift, and J. Done. 1983. Urease assay and ammonia release from leaf tissue. Phytochemistry 22:663-667.

Ilin, S. Z., R. R. Kastori, and D. R. Malencic. 2000. The effect of nickel on superoxide dismutase activity, lipid peroxidation intensity, and oxygen radical quantity in young plants of wheat and maize. Matica Srpska Proceedings for Natural Sciences 98:39-44.

Johnson, C. M., P. R. Stout, T. C. Broyer, and A. B. Carlton. 1957. Comparative chlorine requirements of different plants species. Plant and Soil 8:337-353.

Kabata-Pendias, A., and H. Pendias. 2001. Trace elements in soils and plants, 3rd ed. Boca Raton, Fl.: CRC Press.

Kevresan, S., N. Petrovic, M. Popovic, and J. Kandrac. 1998. Effect of heavy metals on nitrate and protein metabolism in sugar beet. Biologia Plantarum 41:235-240.

Kevresan, S., N. Petrovic, M. Popovic, and J. Kandrac. 2001. Nitrogen and protein metabolism in young pea plants as affected by different concentrations of nickel, cadmium, lead, and molybdenum. Journal of Plant Nutrition 24:1633-1644.

Malavolta, E. 2006. Manual of mineral nutrition of plants. Sao Paulo, Brazil: Editora Agronômica Ceres (in Portuguese).

Malavolta, E., and M. F. Moraes. 2007. Nickel-From toxic to essential nutrient. Better Crops with Plant Food 91:26-27.

Malavolta, E., G. C. Vitti, and S. A. Oliveira. 1997. Evaluation of plant nutritional status: Principles and applications, 2nd ed. Piracicaba, Brazil: Potafos (in Portuguese).

Maranville, J. 1970. Influence of nickel on the detection on nitrate reductase activity in sorghum extracts. Plant Physiology 45:591-593.

Martin, S., D. Saco, and M. Alvarez. 1995. Nitrogen metabolism in Nicotiana rustica L. grown with molybdenum, 2: Flowering stage. Communications in Soil Science and Plant Analysis 26:1733-1747.

Matsumoto, H., T. Yasuda, M. Kobayashi, and E. Takahashi. 1966. The inducible formation of urease in rice plants. Soil Science and Plant Nutrition 12:239-244.

McCullough, H. 1967. Determination of ammonia in whole blood by a direct colorimetric method. Clinica Chimica Acta 17:297-304.

McIlveen, W. D., and J. J. Negusanti. 1994. Nickel in the terrestrial environment. Science of the Total Environment 148:109-138.

Mulder, E. G., R. Boxma, and W. L. V. Veen. 1959. The effect of molybdenum and nitrogen deficiencies on nitrate reduction in plant tissues. Plant and Soil 10:335-355. 
Rahman, H., S. Sabreen, S. Alam, and S. Kawai. 2005. Effects of nickel on growth and composition of metal micronutrients in barley plants grown in nutrient solution. Journal of Plant Nutrition 28:393-404.

Römheld, V. 2001. Physiological basis for symptoms of deficiencies and toxicities of micronutrients and toxic elements in higher plants. In Micronutrients and toxic elements in agriculture, ed. M. E. Ferreira, M. C. P. Cruz, B. van Raij, and C. A. Abreu, 71-85. Jaboticabal, Brazil: CNPq/Fapesp/Potafos (in Portuguese).

Rovers, H., O. A. Camargo, and J. M. A. S. Valadares. 1983. Total and DTPAsoluble nickel in soils of the Sao Paulo state. Revista Brasileira de Ciencia do Solo 7:217-220. (in Portuguese).

Ruter, J. M. 2005. Effect of nickel applications for the control of mouse ear disorder on river birch. Journal of Environmental Horticulture 23:17-20.

Saco, D., S. Martin, and M. Alvarez. 1995. Nitrogen metabolism in Nicotiana rustica L. grown with molybdenum, 1: Vegetative development. Communications in Soil Science and Plant Analysis 26:1719-1732.

SAS. 1996. SAS/STAT user's guide, version 6.11, 4th ed. Cary, N.C.: Statistical Analysis System Institute.

Sato, K. 1969. Antagonism between nickel and molybdenum in citrus. In Proceedings of the First International Citrus Symposium, ed. H. P. Chapman, 1543-1550. Riverside, Calif.: University of California.

Shimada, N., T. Ando, M. Tomiyama, and H. Kaku. 1980. Role of nickel in plant nutrition, I: Effects of nickel on growth of tomato and soybean. Japanese Journal of Soil Science and Plant Nutrition 51:487-492 (in Japanese).

Tan, X. W., H. Ikeda, and M. Oda. 2000. Effects of nickel concentration in the nutrient solution on the nitrogen assimilation and growth of tomato seedlings in hydroponic culture supplied with urea or nitrate as the sole nitrogen source. Scientia Horticulturae 84:265-273.

Welch, R. M. 1981. The biological significance of nickel. Journal of Plant Nutrition 3:345-356.

Wong, P. K., and L. Chang. 1991. Effects of copper, chromium, and nickel on growth, photosynthesis, and chlorophyll a synthesis of chlorella pyrenoidosa 251. Environmental Pollution 72:127-139.

Wood, B. W., C. C. Reilly, and A. P. Nyczepir. 2004. Mouse ear of pecan, I: Symptomatology and occurrence. HortScience 39:87-94.

Wood, B. W., C. C. Reilly, and A. P. Nyczepir. 2006. Field deficiency of nickel in trees: Symptoms and causes. Acta Horticulturae 721:83-97. 